\title{
AIR RADON CONCENTRATION DECREASE IN A WASTE WATER TREATMENT PLANT
}

\author{
B. Juste ${ }^{1, *}$, J. Ortiz $^{2}$, G. Verdú ${ }^{1}, \mathrm{~S}$. Martorell $^{2}$ \\ ${ }^{1}$ ISIRYM, Instituto de Seguridad Industrial, Radiofísica y Medioambiental. Universidad Politécnica de Valencia. \\ Camí de Vera s/n. 46022. Valencia \\ ${ }^{2}$ Laboratorio de Radiactividad Ambiental. Universidad Politécnica de Valencia. Camí de Vera s/n. 46022. \\ Valencia
}

\section{March 2015}

Radon-222 is a naturally occurring gas created from the decay of Radium-226. The long-term health risk of breathing radon is lung cancer. One particular place where indoor radon concentrations can exceed national guidelines is in WasteWater Treatment Plants (WWTPs) where treatment processes may contribute to ambient airborne concentrations. The aim of the paper was to study the radon concentration decrease after the application of corrective measures in a Spanish WWTP. According to first measures, air radon concentration exceeded International Commission Radiologica1 Protection normative ((ICRP) recommends intervention between 400 and $1000 \mathrm{~Bq} / \mathrm{m} 3$ ). Therefore, the wastewater treatment plant improved Mechanical forced ventilation to lower occupational exposure. This measure allowed to increase the administrative controls, since the limitation of workers access to the plant changed from $2 \mathrm{~h} / \mathrm{day}$ (considering a maximum permissible dose of $20 \mathrm{mSv}$ per year averaged over five years) to $7 \mathrm{~h} /$ day.

\section{INTRODUCTION}

Radon-222 is a naturally occurring gas, with intense radiation capacity and a short half-life (3.8 days), created from the decay of Radium-226. Further decay generates alpha rays, which can do extensive damage to internal organs since the radioactive particles get trapped in the lungs, and as those particles break down, they release energy. The long-term health risk of breathing radon is lung cancer. In 1986, the World Health Organization (WHO) declares the carcinogenic nature of radon, confirming the relationship with lung cancer after different global epidemiological studies (1), (2). According to the U. S. Environmental Protection Agency (3), radon is the second most important cause of lung cancer after smoking in many countries.

One particular place where indoor radon concentrations can exceed national guidelines is in WasteWater Treatment Plants (WWTPs) where treatment processes may contribute to ambient airborne concentrations. When the water containing radium is aerated or backwashed, elevated concentrations of radon are released. Therefore, WWTP operators may be at increased risk of $222 \mathrm{Rn}$ inhalation, resulting from water treatment processes when this gas moves from water to air. When radon enters an enclosure with little ventilation, the concentration can reach values that may represent a radiological risk.
According to work places, the International Commission Radiological Protection (4) recommends intervention between 400 and $1000 \mathrm{~Bq} / \mathrm{m}^{3}$.

In Spain, the last regulation regarding the control of radon in workplaces was set in 2012, when the Spanish Consejo de Seguridad Nuclear (5) published the IS-33 (6) which stablish the concentrations measurement of radon in workplaces that might lead to a significant increase in the exposure of workers. The criteria of the Spanish regulation for the annual mean radon concentration during workday sets $600 \mathrm{~Bq} / \mathrm{m}^{3}$ as the reference level without intervention.

The aim of the paper is to give information about air and water radon concentration found in a Spanish WWTP after detecting high radium concentrations inside the water. It consist in an indoor treatment plant, with a $10000 \mathrm{~m}^{3} /$ day flow.

This paper presents the radon concentration values before and after the application of corrective measures.

To evaluate this problem, we used different radon measurement techniques in the water plant placed at Castellón (Spain). We assessed short-term (3 days period) and long term (2-3 months period) measures by monitoring air radon concentration using electrets and alpha spectrometry detector. We also analyzed water radon samples using different techniques. 


\section{OBJECTIVES AND METHODOLOGY}

The main purpose of this study is to present the radon measures performed in a Spanish WWTP where workers were exposed to radon annual average concentration that exceeds the limitation level, 600 $\mathrm{Bq} / \mathrm{m}^{3}$. The paper also presents the methods applied to reduce this exposure and the subsequent radon concentrations decrease.

In this WWTP the two main workers spend an average of 2.5 hours a day inside the treatment plant according to the permanency registries supplied. Occasionally, two other maintenance technics work inside the plant, spending an average of 5 hours per month.

To evaluate the risk, we used passive and active detectors. According to the Spanish Nuclear Security Council (CSN, Consejo de Seguridad Nuclear) safety guide (7), we have used different type of measuring devices: Electrets (provided by RadElec) and RAD7 alpha spectrometry continuous monitoring (provided by Durridge).

This guide also states that the chosen points to place detectors should be representative of the jobs performed in it. The recommendation is to place a detector for each $200 \mathrm{~m}^{2}$. Moreover, detectors must be exposed at least during three months, avoiding the summer period, obtaining in the majority of cases a conservative estimation of the annual average, which ensures an adequate level of protection of workers. According to this protocol, long term measures have been made during the months from February until April 2013 and one year later (after applying constructive and administrative correction measures), from June to September 2014.

Before placing long term detectors, short term measures were taken in the months of January and February 2013 (period of measurement 3 days) to establish a first approximation of the radon levels detected in the plant.

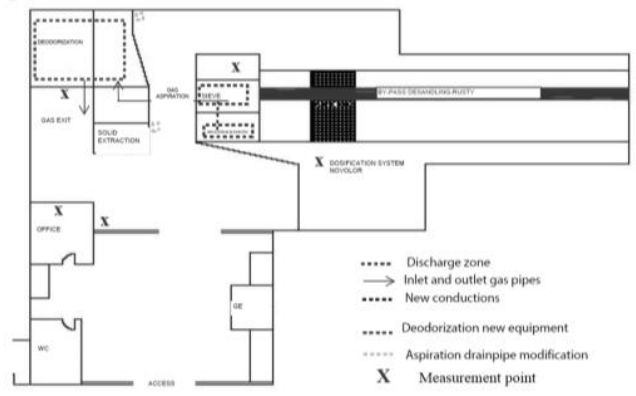

Figure 1. Sampling points at the WWTP

*Corresponding author:bejusvi@iqn.upv.es
Sampling points in the water treatment plant (figure 1) are representative of the jobs performed in the office and solid waste disposal room.

The office room is approximately $4 \times 2 \mathrm{~m}^{2}$. It is next to the pumps moat of the residual water. Detectors were placed at $50 \mathrm{~cm}$ from the wall of the enclosure and at a height of $1 \mathrm{~m}$ above the ground level.

The water treatment room is approximately $200 \mathrm{~m}^{2}$ in which the system of solid waste disposal is placed at the entrance of the residual water. The detectors were placed on the left side of the room and at $2 \mathrm{~m}$ from the ground. The other sampling point was near the first step of coarse grating.

It was also considered convenient to measure the concentration of radon in the annexed building. Since the results of the sampling carried out in January showed that in this adjacent building radon levels were well below the limits of reference, following surveys carried out did not considered necessary to continue measuring radon in this place.

We collected water samples and radon activity concentration in water was measured using the EPERM water measurement kit (8) and the $\mathrm{H} 2 \mathrm{O}$ probe of the RAD7 device.

Measurement procedures have been validated for high and low radon concentrations. Electret measurement was validated at high concentration, $30000 \mathrm{~Bq} / \mathrm{m}^{3}$, at Saelices, in the area of an old uranium mine of ENUSA, near Saelices el Chico (Salamanca, Spain). Electrets were placed in a room at the ground floor where the exposure is more 20 time higher as normal background value in order to test the measurement of natural radiation under typically variations of temperature, pressure and atmospheric pressure (9).

Low concentration measures validation was also performed at the radon Chamber of the radon group of University of Cantabria (Spain). In this case, RAD7and Electrets measurement techniques were certified. Detectors were exposed to two different concentration of radon, one below $200 \mathrm{~Bq} / \mathrm{m}^{3}$ and the other above $1000 \mathrm{~Bq} / \mathrm{m}^{3}$.

\subsection{Radon in air measurement}

Short-term measurements were performed using Electret Passive Environmental Radon Monitor (EPERM) devices in short term (3 day test) and long term (3 months) configuration, using $\mathrm{S}$ chambers and $\mathrm{L}$ chambers respectively.

The RAD7 continual radon measuring instrument from Durridge Company,USA (10), was used also for air 
radon concentration. RAD7 Detector is based on electrostatic collection of alpha-emitters with spectral analysis using a passivated Ion-implanted Planar Silicon detector.

\subsection{Radon in water measurement}

Radon activity concentration in water was measured using the E-PERM water measurement kit. An EPERM is placed in a measurement jar, suspended in the air above the water collected. The lids of the measurement jars are closed and sealed to make them radon-tight. Radon reaches equilibrium between the water and air, which the E-PERM measures. At the end of the desired exposure period, the measurement jars are opened and the E-PERM is removed.

Radon activity concentration in water was also measured using the RAD $\mathrm{H}_{2} \mathrm{O}$ which is an accessory for the RAD7 that enables to measure radon in water. A vial containing a water sample is set up in a closed air loop with the RAD7. The RAD7 pump operates automatically for five minutes to aerate the sample, distributing the radon that was in the water throughout the loop. The RAD7 waits a further five minutes while the $218 \mathrm{Po}$ count rate approaches equilibrium and then the radon concentration in the water is calculated.

\section{RESULTS}

Tables 1 and 2 show the mean air radon concentration obtained in treatment room and office respectively in 2013 , before applying the correction measures. It is observed that in the treatment room the concentration exceeds in all evaluated points $2000 \mathrm{~Bq} / \mathrm{m}^{3}$, which must include a high intervention level control according to CSN guidelines.

Table 1. Mean air radon concentration measured in the treatment room - 2013.

\begin{tabular}{llll}
\hline $\begin{array}{l}\text { Exposure } \\
\text { begins }\end{array}$ & $\begin{array}{l}\text { Exposure } \\
\text { ends }\end{array}$ & Days & $\begin{array}{l}\mathrm{Rn}-222\left(\mathrm{~Bq} / \mathrm{m}^{3}\right) \\
\text { Measured by } \\
\text { electrets }\end{array}$ \\
\hline $21 / 1 / 2013$ & $24 / 1 / 2013$ & 3 & $2590 \pm 129$ \\
$11 / 2 / 2013$ & $14 / 2 / 2013$ & 3 & $2199 \pm 110$ \\
$14 / 2 / 2013$ & $24 / 4 / 2013$ & 69 & $4702 \pm 249$ \\
\hline
\end{tabular}

Table 2. Mean air radon concentration measured in the office -2013.

\begin{tabular}{llll}
\hline $\begin{array}{l}\text { Exposure } \\
\text { begins }\end{array}$ & $\begin{array}{l}\text { Exposure } \\
\text { ends }\end{array}$ & Days & $\begin{array}{l}\text { Rn-222 }\left(\mathrm{Bq} / \mathrm{m}^{3}\right) \\
\text { Measured by } \\
\text { electrets }\end{array}$ \\
\hline $21 / 1 / 2013$ & $24 / 1 / 2013$ & 3 & $2157 \pm 108$ \\
$11 / 2 / 2013$ & $14 / 2 / 2013$ & 3 & $1245 \pm 62$ \\
$14 / 2 / 2013$ & $24 / 4 / 2013$ & 69 & $3156 \pm 159$ \\
\hline
\end{tabular}

Assuming that long term measures register accurately concentration variations, we considered the concentration level at treatment room as $4702 \mathrm{~Bq} / \mathrm{m}^{3}$. For this concentration level in air and assuming an equilibrium factor of 0.4 , the effective dose rate is 26.58 microSieverts per hour, which implies that it was necessary to take measures to reduce radon exposure.

To estimate the effective dose we use the Spanish regulation directives on health protection against ionizing radiation (RD 783/2001) (11). This regulation establishes workplaces conversion factor from effective dose per alpha potential exposure unit $\left(\mathrm{Sv}\right.$ per $\left.\mathrm{Jhm}^{-3}\right)$ of 1.4. This value comes from the ICRP65 publication: "Protection against Radon-222 at Home and at Work". Similarly, the conversion factor for exposure to radon daughter's $2.22 \cdot 10^{-6} \mathrm{mJhm}^{-3}$ per $\mathrm{Bqhm}^{-3}$ (considering an equilibrium factor 0.4 ) comes also from the ICRP 65 .

It must be noted that obtained results in the adjoining outbuildings to the WWTP, around $60 \mathrm{~Bq} / \mathrm{m}^{3}$ are clearly below the reference levels, so tables 1 and 2 show only the results obtained in water treatment plant facilities.

According to these measures, the wastewater treatment plant made the following actions to lower occupational exposure to airborne radon. Since the most important factor in lowering radon concentrations was ventilation, mechanical forced ventilation was improved in the treatment plant, installing a new extractor to renewing air 10 times per hour.

Moreover, administrative controls were also introduced, and it was limited the workers access to the plant to $2 \mathrm{~h} /$ day (considering a maximum permissible dose of $20 \mathrm{mSv}$ per year averaged over five years). Since gamma background dose rate inside the treatment plant was around $0.25 \mu \mathrm{Sv} / \mathrm{h}$, triple of outside values, workers began to wear TLD dosimeters.

Table 3 presents the values obtained from June to September 2014. 
Table 3. Mean air radon concentration measured in the WWTP -2014.

\begin{tabular}{llll}
\hline $\begin{array}{l}\text { Sampling } \\
\text { location }\end{array}$ & Days & $\begin{array}{l}\mathrm{Rn}-222 \\
\left(\mathrm{~Bq} / \mathrm{m}^{3}\right)\end{array}$ & $\begin{array}{l}\mathrm{Rn}-222 \\
\left(\mathrm{~Bq} / \mathrm{m}^{3}\right)\end{array}$ \\
$\begin{array}{l}\text { Measured } \\
\text { by electrets }\end{array}$ & $\begin{array}{l}\text { Measured } \\
\text { by rad7 }\end{array}$ \\
\hline $\begin{array}{l}\text { Office } \\
\text { Treatment } \\
\text { room }\end{array}$ & 3 & $466 \pm 25$ & - \\
$\begin{array}{l}\text { Office } \\
\text { Office }\end{array}$ & 3 months & $692 \pm 40$ & - \\
$\begin{array}{l}\text { Treatment } \\
\text { room }\end{array}$ & 3 months & $625 \pm 37$ & - \\
\hline
\end{tabular}

Comparing values measured in 2014, it can be seen that radon concentration has decreased more than $50 \%$, reaching the low reference level (between 600-1000 $\mathrm{Bq} / \mathrm{m}^{3}$ ) according to CSN guidelines, which implies that workers access to the plant has been increased to 7 $\mathrm{h} /$ day.

Water treated in this WWTP comes from a marsh located at the Mediterranean coast, on the North of the Comunidad Valenciana. According to a previous study by the University of Barcelona (12), the values of radon concentration in water range from 100 to 500 $\mathrm{Bq} / \mathrm{L}$ depending on the sampling point.

Table 4. Water radon concentration

\begin{tabular}{lll}
\hline $\begin{array}{l}\text { Collected and } \\
\text { analyzed }\end{array}$ & $\begin{array}{l}\text { Rn-222 }(\mathrm{Bq} / \mathrm{L}) \\
\text { Measured by } \\
\text { electrets }\end{array}$ & $\begin{array}{l}\text { Rn-222 }(\mathrm{Bq} / \mathrm{L}) \\
\text { Measured by } \\
\text { RAD7 }\end{array}$ \\
\hline $\begin{array}{l}\text { Outlet water } \\
26 / 03 / 2013\end{array}$ & $29 \pm 1.5$ & - \\
\hline $\begin{array}{l}\text { Outlet water } \\
\text { 24/4/2013 }\end{array}$ & $25 \pm 1.3$ & - \\
\hline $\begin{array}{l}\text { Outlet water } \\
\text { 24/3/2014 }\end{array}$ & $16 \pm 0.9$ & - \\
\hline $\begin{array}{l}\text { Outlet water } \\
\text { 27/03/2014 }\end{array}$ & $25 \pm 1.3$ & $24.2 \pm 1.9$ \\
\hline $\begin{array}{l}\text { Outlet water } \\
\text { 3/06/2014 }\end{array}$ & $29 \pm 1.4$ & - \\
\hline $\begin{array}{l}\text { Inlet water } \\
\text { 3/06/2014 }\end{array}$ & $58 \pm 2.9$ & - \\
\hline $\begin{array}{l}\text { Inlet water } \\
6 / 06 / 2014\end{array}$ & $39 \pm 2.1$ & $37.4 \pm 2.4$ \\
\hline $\begin{array}{l}\text { Inlet water } \\
10 / 09 / 2014\end{array}$ & $23 \pm 1.3$ & $25.1 \pm 2.2$ \\
\hline
\end{tabular}

With results obtained in this work, we can conclude that radon levels decreases during its transport from the marsh to the treatment plant where the values are below $100 \mathrm{~Bq} / \mathrm{L}$. Table 4 presents the value of radon concentration in water measures at both years.

\section{CONCLUSIONS}

Because airborne $222 \mathrm{Rn}$ concentrations in water plants can reach levels considered unsafe for workers, it would be prudent to monitor airborne 222Rn concentrations in water plants which aerate water as part of their treatment process. If operators are exposed to higher levels of radon, or are exposed for longer periods of time, then some operators may accumulate enough exposure to exceed the EPA guidelines.

The concentration of radon measured in the WWTP studied was above the $400 \mathrm{~Bq} / \mathrm{m}^{3}$ annual average guideline suggested by ICRP. Administrative controls and construction improvements (air extractor) were carried out, reducing radon concentrations and maintaining within permissible radon concentrations the WWTP air.

\section{REFERENCES}

1. WHO. Air Quality Guidelines for Europe. WHO Regional Publications, European Series, N. ${ }^{\circ}$ 91. Copenhagen. (2000)

2. WHO. Handbook on indoor radon. A public health perspective (2009).

3. U. S. Environmental Protection Agency (USEPA). http://www.epa.gov/

4. International Commission Radiologica1 Protection (ICRP) Statement on Radon. ICRP Ref. 00/902/09. Available at www.icrp.org

5. Consejo de Seguridad Nuclear (CSN). https://www.csn.es/

6. Instrucción IS-33, sobre criterios radiológicos para la protección frente a la exposición a la radiación natural. IS$33, \mathrm{BOE} \mathrm{n}^{\circ} 22$ de 26 de enero de 2012.

7. GS-11.04 "Methodology for the assessment of exposure to radon in the workplace" (2012).

8. Kotrappa, P. , Electret Ion Chamber radon Monitors Measure radon In Water. Health Physics, 64:397-405 (1993).

9. International Intercomparison Exercise on Natural Radiation Measurements under Field Conditions. ISBN 978-84-86116-64-4, (2011).

10. Durridge Company Inc.,RAD 7 Radon Detector, Owner's Manual, Bedford, USA, (2000).

11. Real Decreto 783/2001, «BOE» núm. 178, 2001, pp. 27284-27393.

12. Moreno, V., et al. Resultados preliminaries de los niveles de Radón en la marjal de Peñíscola. Radioprotección num. 60, vol. 17, (2009). 